\title{
PENGEMBANGAN MEDIA PEMBELAJARAN INTERAKTIF BERBASIS ADOBE FLASH PADA MATA PELAJARAN PRAKARYA DAN KEWIRAUSAHAAN MATERI ELEKTRO LISTRIK UNTUK KELAS XI MIPA DAN IPS DI SMA NEGERI 3 SINGARAJA
}

\author{
Kadek Aditya Pradipta Yasa1, Ketut Udy Ariawan², I Wayan Sutaya ${ }^{3}$ \\ ${ }^{123}$ Fakultas Teknik dan Kejuruan Jurusan Pendidikan Teknik Elektro, Universitas Pendidikan Ganesha Singaraja \\ e-mail: pradiptaadit95@gmail.com ${ }^{1}$ udyariawan@undiksha.ac.id ${ }^{2},{\text { wsutaya@undiksha.ac.id }{ }^{3}}^{3}$
}

\begin{abstract}
Abstrak
Penelitian ini bertujuan mengembangkan media interaktif berbasis adobe flash pada mata pelajaran prakarya dan kewirausahaan materi elektro listrik. Penelitian ini bertujuan untuk: (1) mendeskripsikan desain pengembangan media interaktif berbasis adobe flash pada mata pelajaran prakarya dan kewirausahaan materi elektro listrik; (2) menguji validitas hasil pengembangan media berbasis adobe flash pada mata pelajaran prakarya dan kewirausahaan materi elektro listrik. Penelitian ini menggunakan model pengembangan research and development $(\mathrm{RnD})$ dengan langkah-langkah penelitian: analisis kebutuhan, perencanaan media, pengembangan produk, validasi, Tampilan Media pembelajaran interaktif berbasis adobe flash didesain oleh peneliti tampak jelas siswa lebih fokus terhadap pelajaran yang akan dipelajari. Di dalam materi pelajaran di media disisipi konten berupa video ilustrasi, tutorial sebagai pendukung interaktifnya media pembelajaran yang dikembangkan, selain itu agar siswa juga dapat mengetahui bentuk nyata dari materi yang dipelajarinya. Berdasarkan hasil validasi dan ujicoba, diperoleh besaran validitas sebagai berikut: (1) dari ahli materi(guru) $92,85 \%$ pada kualifikasi sesuai, dan (2) dari ahli media 100\%, pada kategori sesuai. Dengan demikian dapat disimpulkan bahwa media interaktif berbasis adobe flash pada mata pelajaran prakarya dan kewirausahaan materi elektro listrik ini sesuai dengan konsep pada materi yang terdapat dimasingmasing mata pelajaran.
\end{abstract}

Kata kunci: pengembangan research and development, media interaktif, elekto listrik

\begin{abstract}
The Development of a Adobe flash based interactive media in subjects Workshops and entrepreneurship material about Electrical electro. This research aimed to (1) describe the design of instructional Adobe flash based interactive media in subjects Workshops and entrepreneurship material about Electrical electro, (2) examine the result's validity instructional Adobe flash based interactive media in subjects Workshops and entrepreneurship material about Electrical electro. This study uses a research and development model that includes the following steps: needs analysis, media planning, product development, validation, individual testings, revising, small group testing, revising, and final products. Based on the results of the validation and testing, the scale validity obtained were as follows: (1) $92.85 \%$ of the expert material, grade is excellent. (2) $89.65 \%$ of media experts (3) The results of individual testing of five people $88.29 \%$ (excellent) (4) The trial results involving a small group of ten respondents $83.17 \%$ (excellent). And the results of field trials of $84.15 \%$ (good) by involving 31 respondents in class XI MIPA 4. Thus, it can be concluded that the Adobe flash based interactive media in subjects Workshops and entrepreneurship material about Electrical electro. is feasible to be used as the learning media
\end{abstract}

Keywords : Research and development study, interactive media, electrical electro 


\section{PENDAHULUAN}

Perkembangan

teknologi dan informasi membawa dampak kemajuan yang sangat pesat terhadap dunia pendidikan. Salah satu contoh penggunaan teknologi dalam dunia pendidikan adalah dengan memanfaatkan teknologi komputer. Teknologi komputer yang sering digunakan oleh guru dalam menyampaikan materi kepada siswa adalah dengan menggunakan media pembelajaran.

Menurut

Rousseau (dalam Ahmadi,dkk, 2001:69), pendidikan adalah memberi kita perbekalan yang tidak ada pada masa anak-anak, akan tetapi kita membutuhkannya pada waktu dewasa. Menurut Ki Hajar Dewantara (dalam Ahmadi, dkk, 2001:69), mendidik adalah menuntun segala kekuatan kodrat yang ada pada anak-anak agar mereka sebagai manusia dan sebagai anggota masyarakat dapat mencapai keselamatan dan kebahagiaan yang setinggi-tingginya. Pendidikan dapat diperoleh dimana saja, kapan saja dan untuk siapa saja baik formal maupun non formal.

Pembelajaran merupakan proses komunikasi, yaitu proses menyampaikan pesan dari sumber pesan melalui media ke penerima pesan. Secara etimologi, media berasal dari Bahasa Latin, merupakan bentuk jamak dari kata "medium" yang berarti "tengah, perantara, atau pengantar" (Asyhar,2012:4). Media memiliki peran yang sangat penting, yaitu suatu sarana atau perangkat yang berfungsi sebagai perantara atau saluran dalam suatu proses komunikasi antara komunikator dengan komunikan (Asyhar, 2012:5). Dengan adanya media pembelajaran ini guru atau pengajar dapat memaparkan materi dengan mudah serta dapat menstimulasi pemikiran peserta didik sehingga materi yang diterima peserta didik mudah dimengerti.

Kegiatan pembelajaran yang dilakukan di SMA Negeri 3 Singaraja khususnya pada mata pelajaran Prakarya dan Kewirausahaan masih menggunakan metode yang konvensional salah satunya ceramah, yaitu pembelajaran yang umumnya masih terfokus pada guru, sedangkan siswa belum terlibat secara aktif dalam pembelajaran. Kenyataan ini belum menunjukkan ke arah pembelajaran yang bermakna.

Menurut hasil observasi dan wawancara melalui guru mata pelajaran prakarya permasalahan yang dihadapi dalam pembelajaran mata pelajaran Prakarya dan Kewirausahaan dalam materi komponen elektro (Listrik) di SMA Negeri 3 Singaraja adalah belum tersedianya media pembelajaran yang memadai yang dapat membuat hasil belajar siswa meningkat, alat dan komponen pendukung pada materi komponen elektro (Listrik) belum terlalu memadai sehingga untuk menyiasati itu semua guru pengajar hanya menggunakan gambar sebagai perumpamaan untuk menjelaskan bukan bentuk real (Nyata) ketika menjelaskan dan menyebabkan siswa kurang dapat menangkap perumpamaan yang di berikan kepada guru.

Selanjutnya nilai untuk mata pelajaran prakarya dan kewirausahaan kelas XI tahun pelajaran 2016/2017 menunjukkan hasil yang kurang. Rata-rata nilai hasil belajar siswa hanya sebesar 70 dibawah nilai kriteria ketuntasan minimal yang ditetapkan sebesar 75 . Kurangnya nilai tersebut kemungkinan dipengaruhi oleh kurangnya minat belajar dan motivasi siswa dalam mengikuti mata pelajaran. Maka, untuk meningkatkan hasil belajar siswa, guru harus bisa memberi motivasi dan menggunakan metode pembelajaran yang dapat membangkitkan minat belajar siswa. Sesuai dengan perkembangan teknologi sekarang, guru dapat menggunakan media yang interaktif untuk membangkitkan minat belajar peserta didik.

Maka, diperlukan media pembelajaran yang dapat membantu siswa agar lebih interaktif dan juga membuat siswa dapat berfikir lebih kritis dan dapat membangun semangat dan motivasi siswa agar belajar lebih baik, sehingga mendapatkan hasil belajar yang memuaskan.

Berdasarkan latar belakang di atas yang telah diuraikan, maka perlu dirumuskan permasalahan dalam penelitian ini adalah bagaimana mengembangkan media pembelajaran interaktif berbasis adobe flash pada mata 
pelajaran prakarya dan kewirausahaan materi elektro listrik untuk kelas XI MIPA dan IPS di SMA Negeri 3 Singaraja?

Dari rumusan yang dikemukan di atas adapun tujuan dari penelitian ini adalah untuk menghasilkan media pembelajaran interaktif berbasis adobe flash dalam mata pelajaran prakarya dan kewirausahaan materi elektro listrik dimensi pada kelas XI MIPA dan IPS di SMA Negeri 3 Singaraja.

Dalam penelitian ini peneliti membatasi pada masalah yang mencangkup :

1. Mata pelajaran yang akan dijadikan media pembelajaran hanya mata pelajaran prakarya dan kewirausahaan dengan materi elektro listrik.

2. Sampel yang akan diteliti terletak di SMA Negeri 3 Singaraja pada kelas XI Jurusan MIPA dan IPS.

3. Software yang digunakan dalam pembuatan desain media serta peletakan materi menggunakan software Adobe Flash CS 6, 3Dmax 2010, After effect, adobe illustrator, adobe premiere, photoshop, dan coreldraw, serta audacity.

4. pembuatan video pada materi teknik pemasangan kabel dan lilitan menggunakan software adobe premiere dan after effect.

\section{Media Pembelajaran}

Media pembelajaran berasal dari dua kata yaitu media dan pembelajaran. Secara etimologis, media berasal dari Bahasa Latin, merupakan bentuk jamak dari kata medium yang berarti tengah, perantara, atau pengantar. Menurut Bovee (dalam Asyhar, 2012:4), istilah perantara digunakan karena fungsi media sebagai perantara atau pengantar suatu pesan dari si pengirim (sender) kepada si penerima (reicever) pesan. The Association for Educational Communication and Technology (AECT) (dalam Asyhar, 2012:4) menyatakan bahwa media adalah apa saja yang digunakan untuk menyalurkan informasi. Menurut Suparman (dalam Asyhar, 2012:4), media merupakan alat yang digunakan untuk menyalurkan pesan dan informasi dari pengirim pesan kepada penerima pesan.

Media pembelajaran dapat dikatakan sebagai semua alat yang dapat digunakan sebagai media dalam pembelajaran. Secara terminologis, terdapat berbagai definisi yang diberikan tentang media pembelajaran. Media memiliki peran yang sangat penting, yaitu suatu sarana atau perangkat yang berfungsi sebagai perantara atau saluran dalam suatu proses komunikasi antara komunikator dengan komunikan (Asyhar, 2012:5). Berdasarkan definisi tersebut, dapat dikatakan bahwa proses pembelajaran merupakan proses komunikasi.

Media pembelajaran dapat dikatakan interaktif apabila peserta didik tidak hanya melihat dan mendengar tetapi secara nyata berinteraksi langsung dengan media pembelajaran itu. Peserta didik dilibatkan dalam penggunaan media pembelajaran.

Proses pembelajaran mengandung lima komponen komunikasi, guru (komunikator), bahan pembelajaran, media pembelajaran, siswa (komunikan), dan tujuan pembelajaran. Jadi, media pembelajaran adalah segala sesuatu yang dapat digunakan untuk menyalurkan pesan (bahan pembelajaran), sehingga dapat merangsang perhatian, minat,pikiran, dan perasaan siswa dalam kegiatan belajar untuk mencapai tujuan belajar. (Santyasa, 2007).

Sesuai dengan karakteristik media pembelajaran dibagi menjadi empat jenis, yaitu media audio, media visual, media audio visual, dan multimedia. Multimedia merupakan penggabungan dari dua kata yaitu "multi" dan "media". Multi berarti banyak sedangkan media merupakan bentuk jamak dari medium yang berarti perantara. Istilah multimedia digunakan untuk menyatukaan teknologi digital dan analog di bidang entertainment, publishing, communication, marketing, advertising, dan juga commercial (Asyhar, 2012:75). Dari berbagai macam media 
yang dapat digunakan sebagai media pembelajaran, salah satunya berupa media berbasis komputer untuk menyajikan materi pelajaran sebagai media interaktif.

Menurut Wahono (2006) terdapat 3 aspek penilaian yaitu aspek rekayasa perangkat lunak, aspek instructional design (desain pembelajaran) dan aspek komunikasi visual. Kriteria penilaian termasuk mekanisme penjurian tidak digabungkan menjadi satu, tetapi dipisah dan tiap aspek dinilai oleh orang yang kompeten di aspek tersebut.

Media interaktif adalah suatu media yang dilengkapi dengan alat pengontrol yang dapat dioperasikan oleh pengguna, sehingga pengguna dapat memilih apa yang dikehendaki untuk proses selanjutnya. Contoh media interaktif adalah pembelajaran interaktif, aplikasi game, dan lain-lain. Adapun karakteristik media pembelajaran interaktif adalah sebagai berikut: (1) Media pembelajaran harus memiliki lebih dari satu media baik dalam bentuk audio, audiovisual, dan visual ; (2) Memiliki kekuatan variasi akan warna, dan resolusi objek ; (3) Bersifat interaktif dan memiliki tipe-tipe pembelajaran yang bervariasi ; dan (4) Bersifat interaktif dan memiliki tipe-tipe pembelajaran yang bervariasi.

Media pembelajaran interaktif memiliki beberapa manfaat yang dapat mendukung proses pembelajaran agar berjalan baik. Secara umum manfaat media pembelajaran menjadikan proses pembelajaran akan lebih menarik, lebih interaktif, kualitas belajar siswa dapat ditingkatkan, proses belajar mengajar dapat dilakukan dimana saja dan kapan saja, serta sikap siswa dalam pembelajaran dapat ditingkatkan. Oleh karena itu, media pembelajaran memberikan solusi dari berbagai masalah karena tipe belajar siswa yang berbeda. Untuk dapat menghasilkan media interaktif yang menarik, salah satu aplikasi yang dapat digunakan adalah adobe flash. Adobe Flash (pada awalnya bernama Macromedia Flash) adalah salah satu perangkat lunak komputer yang merupakan produk unggulan Adobe Systems. Adobe Flash digunakan untuk membuat gambar vektor maupun gambar animasi tersebut. Berkas yang dihasilkan dari perangkat lunak ini mempunyai file extension .swf dan dapat diputar di penjelajah web yang telah dipasangi Adobe Flash Player. Flash didesain dengan kemampuan untuk membuat animasi 2 dimensi yang handal dan ringan sehingga flash banyak digunakan untuk membangun dan memberikan efek animasi pada website, CD Interaktif, dan yang lainnya. Keunggulan yang dimiliki oleh Flash ini adalah ia mampu diberikan sedikit code pemograman baik yang berjalan sendiri untuk mengatur animasi yang ada di dalamnya atau digunakan untuk berkomunikasi dengan program lain seperti HTML, PHP, dan Database dengan pendekatan XML, dapat dikolaborasikan dengan web, karena mempunyai keunggulan antara lain kecil dalam ukuran file outputnya.

Penelitian pengembangan media pembelajaran ini diterapkan pada mata pelajaran prakarya dan kewirausahaan dengan materi elektro listrik. Pada materi elektro listrik terdapat dua sub materi yaitu komponen elektronika dan komponen instalasi listrik, namun dalam penelitian ini peneliti memfokuskan pada sub materi komponen instalasi listrik saja. Pokok bahasan pada sub materi ini adalah pengertian listrik, system jaringan listrik, komponen dan bahan instalasi listrik, simbol - simbol instalasi listrik, dan pilinan/sambungan kabel.

\section{METODE}

Penelitian pengembangan Media Pembelajaran Interaktif Berbasis Adobe Flash Pada Mata Pelajaran Prakarya dan Kewirausahaan yang peneliti gunakan adalah penelitian pengembangan (research and development) menganut teori borg and gall yaitu penelitian yang dimana penelitiaan ini bertujuan untuk menghasilkan produk, mengembangkan, memperluas, dan menggali lebih dalam teori dari suatu ilmu pengetahuan tertentu.

Menurut Sugiyono (2015:409-426), terdapat 10 langkah dalam penelitian $R$ \& $\mathrm{D}$ adalah sebagai berikut: (1) Potensi dan

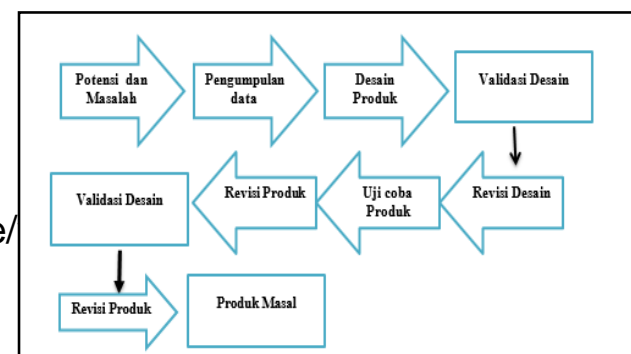


masalah, (2) Pengumpulan data, (3) Desain produk, (4) Validasi desain, (5) Revisi desain, (6) Ujicoba produk, (7) Revisi produk, (8) Revisi produk, (9) Validasi desain, dan (10) produk masal

Gambar 1. Langkah langkah metode penelitan RnD menurut Sugiono (2009)

Dalam Penelitian pengembangan ini, peneliti tidak melakukan langkah uji coba pemakaian dan produksi masal hanya sampai dengan revisi produk, karena produk yang dikembangkan yaitu media pembelajaran interaktif bebasis adobe flash tidak diproduksi secara masal atau luas, karena jika ingin dilakukan produk masal harus ada kerja sama antara pihak sekolah dan juga dengan instansi terkait dengan media yang akan di produksi secara masal.

\section{Potensi masalah}

Menurut Sugiyono (2015:409)

"Penelitian ini berangkat dari adanya potensi dan masalah". Potensi adalah segala sesuatu yang bila didayagunakan akan memiliki nilai tambah. Masalah juga bisa dijadikan sebagai potensi, apabila dapat mendayagunakannya. Berdasarkan hasil observasi, pada Jurusan MIPA dan IPS di SMA Negeri 3 Singaraja kurang memiliki media yang mampu menunjang berjalanya pembelajaran, serta guru lebih banyak menerangkan kepada siswa menggunakan gambar saja, oleh karena itu media visual sangat dibutuhkan oleh siswa untuk mempermudah memberi gambaran pemahaman siswa terkait materi yang akan dipelajari, selain itu sekolah juga kurang memiliki refrensi dalam menunjang proses belajar mengajar dikelas, tetapi teknologi yang berkembang disekolah untuk menunjang pembelajaran sudah modern, salah satu contoh siswa banyak menggunakan laptop dan juga komputer di $\mathrm{LAB}$, tetapi hal tersebut kurang dimanfaatkan oleh guru pengajar.

\section{Pengumpulan data \\ Pengumpulan data merupakan bagian terpenting dari sebuah penelitian. "Terdapat dua hal utama yang mempengaruhi kualitas data hasil}

penelitian, yaitu kualitas instrumen penelitian dan kualitas pengumpulan data" (Sugiyono, 2011: 137). Pada tahap ini pengumpulan data dilakukan dengan melakukan wawancara kepada siswa dan guru terkait mata pelajaran yang terdapat dalam Jurusan MIPA dan IPS sehingga produk yang dihasilkan sesuai dengan kebutuhan

\section{Desain Produk}

Dalam desain produk Media pembelajaran interaktif berbasis adobe flash ini peneliti mengembangkan media pembelajaran yang sudah ada di sekolah. Akan tetapi di tambahkan konten multimedia berupa video tutorial serta video simulasi yang nantinya mampu menarik perhatian siswa ketika belajar materi elektro listrik

\section{Validasi Desain}

Pada tahap ini media yang dibuat oleh peneliti akan divalidasi oleh validator yaitu seorang yang berkopeten di bidang IT dan juga seorang guru mata pelajaran prakarya dan kewirausahaan yang mengajar materi elektro listrik. Validator ini merupakan rekomendasi dari pembimbing yang nantinya akan menilai media dan memberi masukan tentang media yang dibuat peneliti.

\section{Revisi Desain}

Tahap selanjutnya akan dilakukan revisi desain, hal ini dilakukan apabila hasil dari validasi media interaktif berbasis adobe flash memperoleh hasil yang kurang memuaskan oleh validator. Apabila hasil validasi memperoleh hasil yang memuaskan dari validator, maka dilanjutkan dengan uji coba produk.

\section{Uji Coba Produk}

Produk yang telah divalidasikan oleh ahli kemudian diujicobakan pada siswa. Uji coba produk dilakukan dengan melakukan uji perorangan, uji coba kelompok kecil, dan uji coba lapangan. Data yang diperoleh kemudian dianalisis dan digunakan untuk memperbaiki atau merevisi produk yang dikembangkan. Pada uji coba lapangan dilakukan dengan 
memperhatikan ketertarikan siswa dalam membaca isi materi dari Media Pembelajaran interaktif, selanjutnya angket atau kuisioner diberikan kepada siswa untuk menilai Media Interaktif yang digunakan. Dari hasil penilaian angket siswa tersebut akan dianalisis sehingga terlihat bahwa dari Media Pembelajaran interaktif berbasis adobe flash layak atau tidaknya sebagai bahan referensi atau media pembelajaran

\section{Revisi Produk}

Setelah mendapatkan hasil uji coba produk media interaktif berbasis adobe flash, selanjutnya dilakukan analisa. Apabila hasil uji coba produk memperoleh hasil yang kurang memuaskan dari siswa, maka dilakukan perbaikan produk

Subjek dalam penelitian ini adalah siswa kelas XI MIPA dan IPS di SMA Negeri 3 Singaraja.

Alasan pengambilan subjek ini dikarenakan pada Jurusan MIPA dan IPS di SMA Negeri 3 Singaraja kurang memiliki media yang mampu menunjang berjalanya pembelajaran, serta guru lebih banyak menerangkan kepada siswa menggunakan gambar saja, oleh karena itu media visual sangat dibutuhkan oleh siswa untuk mempermudah memberi gambaran pemahaman siswa terkait materi yang akan dipelajari, selain itu sekolah juga kurang memiliki refrensi dalam menunjang proses belajar mengajar dikelas.

Produk yang dihasilkan pada penelitian ini yaitu berupa Media pembelajaran interaktif berbasis adobe flash dengan tamplian flash player yang dimana didalamnya terdapat video tutorial dan simulasi yang nantinya dapat menarik perhatian siswa untuk ingin membaca serta mempelajari mata pelajaran prakarya dan kewirausahaan materi Elektro Listrik. Hasil rancangan produk Media Pembelajaran interaktif berbasis adobe flash dalam mata pelajaran Prakarya dan kewirausahaan materi elektro listrik di Jurusan MIPA dan IPS harus dilakukan uji validasi.

Hasil dari kegiatan validitas ini dilakukan melalui satu tahap yakni: a) riview oleh ahli isi bidang studi atau mata pelajaran, ahli desain media pembelajaran (dosen). Instrumen yang digunakan untuk mengumpulkan data dalam penelitian pengembangan ini adalah angket. Angket digunakan untuk mengumpulkan data tahap I hasil riview dari ahli isi bidang studi atau mata pelajaran serta ahli media pembelajaran. Pada angket tersebut diisi pula kritik dan saran yang berguna untuk merevisi ataupun menambahkan media pembelajaran interaktif yang dibuat. Dalam penelitian pengembangan ini , teknik analisis data tahap I yang digunakan adalah teknik deskriptif persentase dengan rumus.

$$
P=\frac{f}{N} \times 100 \%
$$

$\mathrm{P}=$ persentase skor

$\mathrm{f}=$ jumlah skor yang diperoleh

$\mathrm{N}=$ jumlah skor maksimum.

Validator materi dan media akan menjawab pertanyaan yang diberikan oleh peneliti dengan memberi skor sesuai dengan rubrik validasi penilaian yang diberikan oleh peneliti (Skor tertinggi=1 dan skor terendah $=0$ ), dimana agar mendapat jawaban yang tegas terhadap permasalahan yang ditanyakan.

Untuk dapat memberikan makna dalam pengambilan keputusan digunakan ketetapan seperti pada table 1.

Tabel 1. Rentangan Persentase dan Kriteria Kualitatif Uji perkembangan Media

\begin{tabular}{lcc}
\hline No & Rentangan Persentase & Kriteria Kualitatif \\
\hline 1 & $50 \%-100 \%$ & Sesuai \\
\hline
\end{tabular}




\begin{tabular}{lll}
\hline 2 & $0 \%-49 \%$ & Tidak Sesuai \\
\hline
\end{tabular}

\section{Desain produk}

Perencanaan desain produk merupakan skesta awal dari media interaktif berbasis adobe flash yang akan dibuat. Media pembelajaran interaktif berbasis adobe flash merupakan salah satu media pembelajaran yang sudah lama atau sering digunakan oleh guru pada umumnya, hal ini karena penggunaan aplikasi ini sangatlah mudah serta ketika pembuatan konten dan media lebih mudah digunakan.

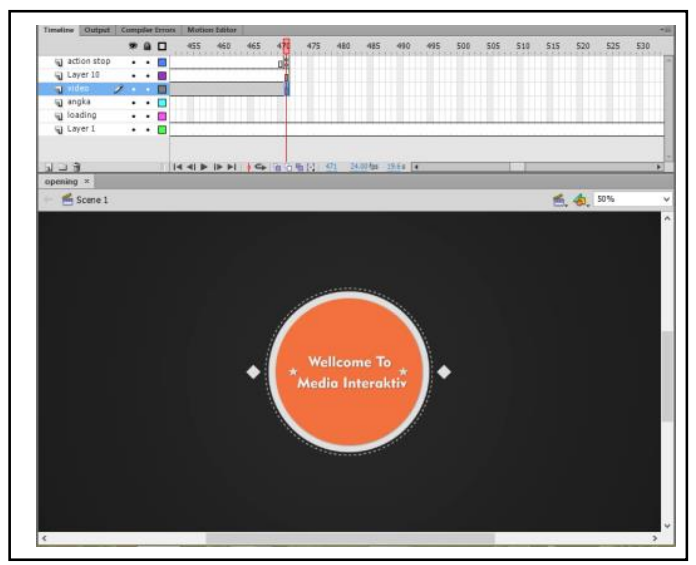

Gambar 2. Tampilan awal media interaktif

\section{Perancangan Produk}

\section{a. Alat dan Bahan}

Dalam perencanaan desain media interaktif berbasis adobe flash player dibutuhkan beberapa alat dan bahan yaitu

(1) materi elektro listrik dalam modul yang diberikan oleh guru pengempu mata pelajaran prakarya dan kewirausahaan.

(2) perangkat keras berupa laptop

(3) perangkat lunak berupa Adobe photoshop CS 6, Adobe flash CS 6. Adobe illustrator CS6, Adobe After effect CS 6, adobe premiere CS 6 , dan corel drwaw X7.

(4) gambar pendukung dari materi yang akan di bahas, dapat menggunakan Photoshop untuk membuat serta mengedit file gambar

b. Proses Pembuatan

Setelah alat dan bahan dipersiapkan maka dilakukan proses pembuatan sebagai berikut.

1. pembuatan gambar tampilan header pada media interaktif dengan membuat gambar jpg menjadi png.

Membuat gambar tampilan jpg ke png dengan cara membuka aplikasi adobe illustrator dengan cara membuat dengan lassotool dan setelah diedit sedemikian rupa simpan dengan format .png dengan cara saveAs lalu merubah formatnya dengan cara memhilih png lalu pilih save.

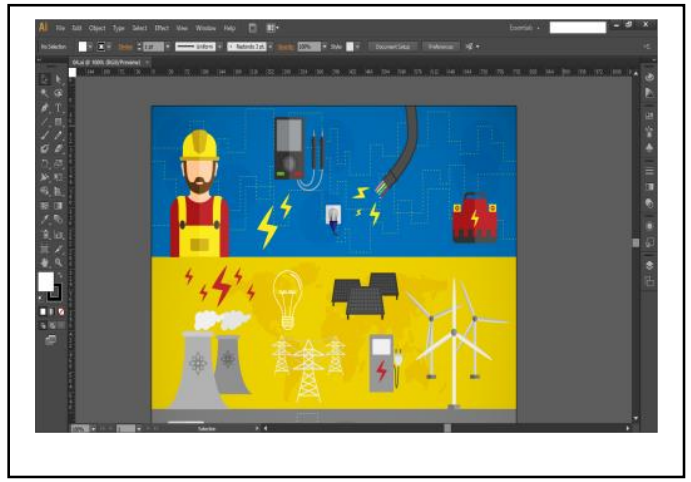

Gambar 3. Pembuatan header tampilan awal media

2. Pembuatan media interaktif memasukan materi jenis kabel instalasi listrik maupun video animasi dengan menggunakan adobe flash CS 6.

Langkah Cara memasukkan import video kedalam adobe flash mulamula membuat kayframe pada

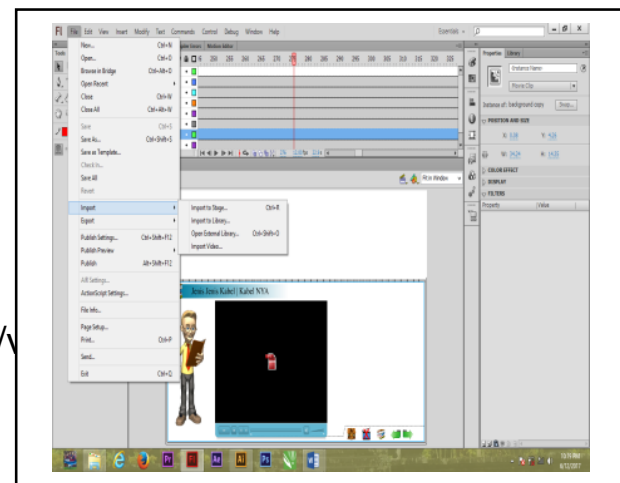


template lanjut terlebih dahulu menginput teks dengan mengunakan teks tool lalu untuk menginport video tinggal pilih menu file import video.

Gambar 4. Import video ke media

\section{HASIL DAN PEMBAHASAN}

Dalam

validitas

hasil

pengembangan media pembelajaran interaktif berbasis adobe flash ini akan dipaparkan empat hal pokok, pengumpulan data, (2) desain produk, (3) Validasi Desain, (4) revisi desain Keempat data tersebut akan disajikan secara berturut-turut sesuai dengan hasil yang diperoleh sebagai berikut.

Penelitian ini dilakukan untuk mengetahui bagaimana mengembangkan media pembelajaran interaktif berbasis adobe flash pada mata pelajaran prakarya dan kewirausahaan materi elektro listrik untuk siswa kelas XI MIPA dan IPS di SMA Negeri 3 Singaraja. Berikut ini perbandingan sebelum (Media Pembelajaran ) dengan sesudah Media Pembelajaran ) dikembangkan.

Berdasarkan hasil wawancara secara tak langsung dokumentasi dan hasil observasi dalam pengumpulan data pada penelitian tahap I, maka diperoleh data bahwa untuk mendukung ketercapaian pemahaman siswa, perlu dilakukan identifikasi kebutuhan untuk pembuatan media interaktif berbasis adobe flash sebagai referensi atau media pembelajaran pada kelas XI MIPA dan IPS di SMA Negeri 3 singaraja.

Desain produk pada penelitian tahap I ini merupakan wujud dari media interaktif berbasis adobe flash yang dibuat - Berikut ini fungsi dari navigasi dalam media interaktif berbasis adobe flash.

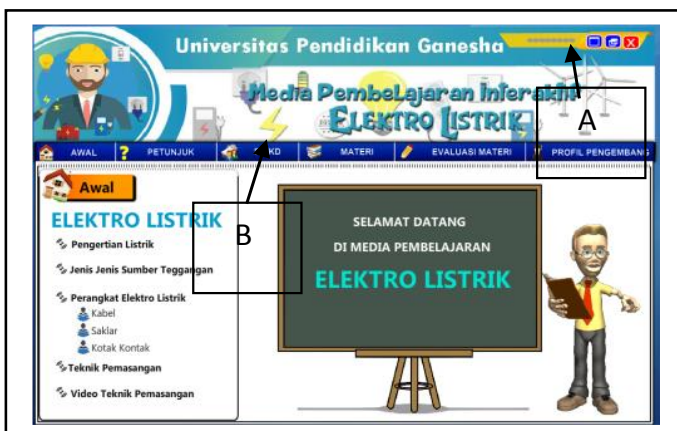

nttps://ejournal.unamiksna.ac.Ia/maex.pnp/JPTK/issue/view/716
Gambar 5. Tampilan media interaktif

Keterangan:

(A) Menu navigasi suara dan close media

(B) Menu navigasi media ke konten media

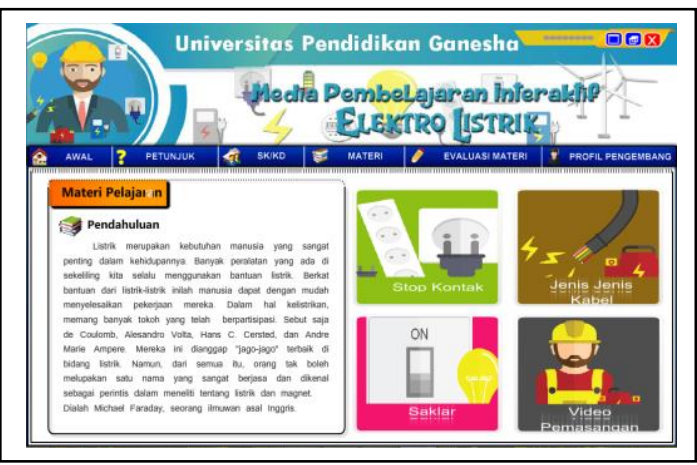

Gambar 6. Tampilan konten materi

Produk akhir dari penelitian ini adalah media pembelajaran interaktif berbasis adobe flash pada mata pelajaran prakarya dan kewirausahaan dengan materi "Elektro Listrik" pada kelas XI MIPA dan IPS di SMA Negeri 3 Singaraja. Media pembelajaran interaktif berbasis adobe flash diuji oleh bapak I Made Sriana, S.Pd. selaku ahli mata pelajaran prakarya dan kewirausahaan.

Setelah dikonversikan dengan tabel konversi, persentase tingkat pencapaian $92,85 \%$ berada pada kualifikasi sesuai dan tidak perlu direvisi. Akan tetapi saran yang diberikan validator kepada peneliti adalah agar background dan juga font disesuaikan warna serta ukuran yang ada pada media karena saya kurang suka tipe font yang digunakan, tetapi untuk yang lainya udah sesuai dengan kriteria yang ditetapkan.

Hasil evaluasi oleh ahli media bapak Prof. Dr. I Made Candiasa, M.I.Kom. Validator kedua adalah rekomendasi dari pembimbing karena beliau ada profressor dan juga ahli di bidan komputer dan TIK serta di bidang media pendidikan, setelah dikonversikan dengan tabel konversi, persentase tingkat pencapaian $100 \%$ berada pada kualifikasi sesuai . akan tetapi ada masukan yang diberikan oleh validator kepada peneliti yaitu sisipkan video pemasangan stop kontak 
dan saklar, akan tetapi dipisahkan videonya agar media tidak lambat ketika digunakan .

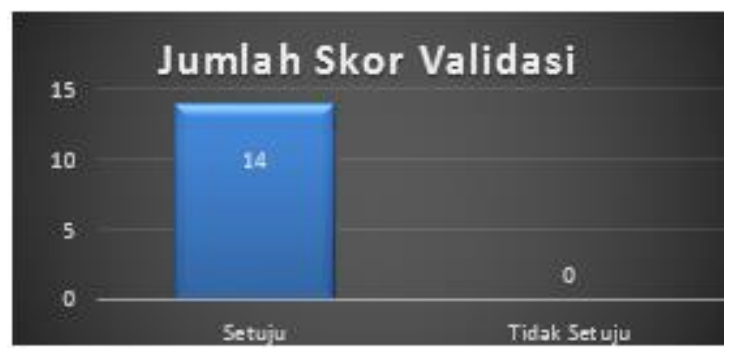

Gambar 8. Grafik jumlah skor validasi ahli media

Kualifikasi masing masing validator terdapat di tabel 3.

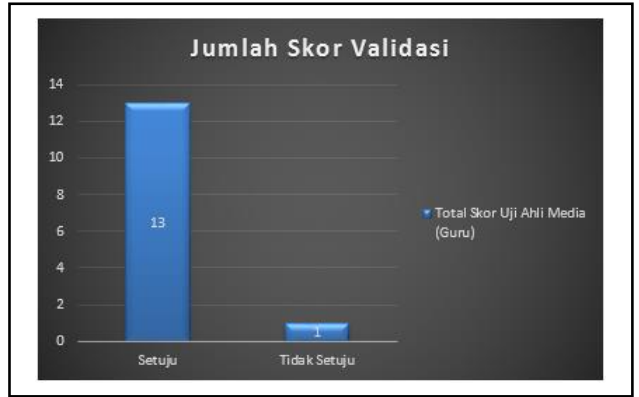

Gambar 7. Grafik jumlah skor validasi ahli isi ( guru mata pelajaran prakarya)

Tabel 3. Kualifikasi Nilai dari Masing - Masing Responden

\begin{tabular}{lccc}
\hline No & Responden & Nilai $(\%)$ & Kualifikasi \\
\hline 1 & Uji ahli isi & $92,85 \%$ & Sesuai \\
\hline 2 & Uji ahli media & $100 \%$ & Sesuai \\
\hline
\end{tabular}

\section{Pembahasan}

Penelitian ini dilakukan untuk mengetahui bagaimana mengembangkan media pembelajaran interaktif berbasis adobe flash dalam mata pelajaran prakarya dan kewirausahaan materi elektro listrik untuk kelas XI MIPA dan IPS di SMA Negeri 3 Singaraja. Berikut ini perbandingan sebelum (media Pembelajaran) dengan sesudah (media pembelajaran) dikembangkan.

Tabel perbedaan media pelajaran yang sudah ada dan media interaktif yang di kembangkan.

Table 4. perbandingan media yang sudah ada dan media yang di kembangkan

\begin{tabular}{|l|lr|}
\hline \multicolumn{1}{|c|}{$\begin{array}{c}\text { Media yang } \\
\text { sudah ada }\end{array}$} & \multicolumn{2}{|c|}{$\begin{array}{c}\text { Media interaktif } \\
\text { yang di } \\
\text { kembangkan }\end{array}$} \\
\hline $\begin{array}{l}\text { Berbentuk } \\
\text { persentasi biasa }\end{array}$ & $\begin{array}{l}\text { Media berbentuk } \\
\text { audio visual dan } \\
\text { berisi rid suara } \\
\text { penerang materi }\end{array}$ \\
\hline $\begin{array}{l}\text { Belum memuat } \\
\text { video }\end{array}$ & $\begin{array}{l}\text { Memuat video } \\
\text { simulasi, dan video } \\
\text { tutorial. }\end{array}$ \\
\hline
\end{tabular}

Validasi desain yang dilakukan peniliti menggunakan instrument dengan skala Guttman hal ini bertujuan agar peneliti mendapatkan jawaban yang tegas terhadap suatu permasalahan yang ditanyakan.

Hasil uji validasi dari validator dengan menggunakan angket menyatakan bahwa media pembelajaran interaktif berbasis adobe flash pada mata pelajaran prakarya dan kewirausahaan materi elektro listrik sudah sesuai dengan konsep yang terdapat pada materipelajaran yang terdapat dimasingmasing mata pelajaran.

\section{KESIMPULAN DAN SARAN}

Berdasarkan hasil penelitian dan pembahasan yang telah diuraikan, Dalam perancangan media pembelajaran interaktif berbasis adobe flash adapun beberapa langkah - langkah penelitian yang dilakukan, yaitu Potensi Masalah, Pengumpulan Data, Desain Produk, Validasi Desain, Revisian Desain. 
Pengembangan media pembelajaran interaktif berbasis adobe flash dalam mata pelajaran prakarya dan kewirausahaan pada materi elektro listrik di kelas XI MIPA dan IPS di SMA Negeri 3 Singaraja dengan menambahkan video tutorial serta simulasi yang berkaitan dengan materi pelajaran. Hasil yang diperoleh dari mengembangkan media interaktif berbasis adobe flash terdapat tutorial dan juga simulasi pemasangan kotak kontak dan juga saklar yang mudah dipahami oleh siswa kelas XI MIPA dan IPS di SMA Negeri 3 Singaraja.

$\begin{array}{ccc}\text { Hasil uji validasi dari validator } & \text { mengunakan } & \text { angket }\end{array}$ menyatakan media pembelajaran interaktif berbasis adobe flash pada mata pelajaran prakarya dan kewirausahaan materi elektro listrik untuk kelas XI MIPA dan IPS Sesuai dengan Konsep materi yang terdapat di materi pembelajaran. Serta hasil dari media pembelajaran mampu meningkatkan hasil belajar siswa di kelas XI MIPA dan IPS di SMA Negeri 3 Singaraja walaupun tidak signifikan (data terlampir pada lampiran). Selain itu ketika media interaktif berbasis adobe flash yang dikembangkan ini diterapkan ke salah satu kelas XI baik dalam jurusan MIPA dan IPS respon siswa terhadap pembelajaran sangatlah positif serta wawasan pengetahuan yang didapat oleh siswa lebih banyak ketimbang ketika melakukan pembelajaran dengan tidak menggunakan media.

Berdasarkan simpulan, adapun saran yang disampaikan berkaitan dengan pengembangan media interaktif berbasis adobe flash ini adalah sebagai berikut. Pertama, saran bagi siswa adalah agar menggunakan media pembelajaran interaktif berbasis adobe flash dalam mata pelajaran prakarya dan kewirausahaan dalam materi elektro listrik untuk kelas XI di Jurusan MIPA dan IPS, sebagai salah satu refrensi dalam memahami materi pembelajaran.

Kedua, Saran bagi guru adalah agar media pembelajaran interaktif berbasis adobe flash ini diterapan lebih lanjut dalam proses pembelajaran dan menyesuaikan dengan kurikulum terlebih lagi penguasaan di bidang IT, sehingga dapat mencapai tujuan pembelajaran yang efektif dan efisien.

Ketiga, Saran bagi kepala sekolah adalah agar mengelola media pembelajaran ini dengan baik, sebagai salah satu koleksi sumber belajar yang dapat dimanfaatkan oleh guru maupun siswa.

Keempat, saran bagi peneliti lain pengembangan media pembelajara interaktif berbasis adobe falsh dalam mata pelajaran Prakarya dan kewirausahaan materi elektro listrik di klas XI Jurusan MIPA dan IPS di SMA Negeri 3 Singaraja dapat dikembangkan secara lanjut guna untuk melengkapi mata pelajaran yang belum terdapat di dalam media Interaktif, sehingga nantinya media interaktif ini menjadi utuh dalam CD interaktif untuk melanjutkan penelitian ini dengan ruang lingkup yang lebih luas.

\section{DAFTAR PUSTAKA}

Ahmadi, Abu. dkk. 2001. Ilmu Pendidikan Edisi 2. Jakarta: PT RINEKA CIPTA.

Arimbawa, Komang. 2016. "Pengembangan Media Pembelajaran CD Interaktif Dalam Mata Pelajaran Teknik Animasi 3 Dimensi di SMK Negeri 3 Singaraja". Skripsi (tidak diterbitkan). Jurusan Pendidikan Teknik Elektro, Undiksha.

Depari, Ganti. 2003. Ketrampilan Listrik. Bandung: Penerbit M2S.

Effendi, Usman. 2002. Modul Istalasi Listrik. Bandung: TEDC.

Ferweda, lan. 2001. Listrik dalam Rumah Tangga. Bandung: PPPG Teknologi Bandung.

Koyan, I Wayan. 2011. Assesmen dalam Pendidikan. Singaraja: Universitas Pendidikan Ganesha Press. 
Rayandra, Asyhar. 2012. Kreatif Mengembangkan

Pembelajaran. Media

Referensi.

Jakarta:

Sanuaka, Ambhara. Udy Ariawan dan Sutayai. 2016. "Pengembangan Media Electronic Book (E-Book) Interaktif Multimedia dalam Mata Pelajaran Teknik Animasi 3D dan Teknik Animasi 2D di Jurusan Multimedia SMK Negeri 3 Singaraja". Jurnal Pendidikan Teknik Elektro. Volume 8, No.1. Tersedia di http://ejournal. undiksha.ac.id. (diakses tanggal 7 Januari 2017).
Slameto. 2010. Belajar dan Faktor Faktor yang Mempengaruhinya. Jakarta: Rineka Cipta.

Sigiono. 2009. Metode Penelitian Kualitatif ,Kuantitatif, dan RnD. Bandung: Alfabeta.

Wojowasito, Soewojo dan W J S Poerwadiminta. 1997. Kamus Lengkap Inggris-Indonesia Indonesia-Inggris dengan Ejaan Yang Disempurnakan (EYD). Bandung: Hasta. 